\title{
Currency Substitution in Anticipation of EU Accession
}

\author{
Hans Genberg \\ Graduate Institute of International Studies, Geneva
}

\begin{abstract}
Countries in Eastern and Central Europe that are likely to join the European Union will eventually also join the European Monetary Union. The process of accession will entail a transition period at the end of which it is certain that the domestic currency will be replaced by the Euro. This paper argues that this programmed demise of the domestic currency may bring about significant spontaneous euroization already during the transition period.

If the euro is adopted by the private sector in anticipation of the official changeover, the country incurs a resource cost in the form of lost seignorage. Compared to the initial members of the EMU that could print Euros equal to the outstanding monetary base, a country where euroization takes place before the entry into the EMU will use real resources to obtain the Euros. The paper proposes ways to deal with this difference in treatment.
\end{abstract}

(C) The Authors.

All rights reserved. No part of this paper may be reproduced without the permission of the authors. 


\title{
Currency substitution in anticipation of EU accession
}

\author{
by \\ Hans Genberg \\ Graduate Institute of International Studies \\ Geneva, Switzerland
}

May 4, 2002

\begin{abstract}
Countries in Eastern and Central Europe that are likely to join the European Union will eventually also join the European Monetary Union. The process of accession will entail a transition period at the end of which it is certain that the domestic currency will be replaced by the Euro. This paper argues that this programmed demise of the domestic currency may bring about significant spontaneous euroization already during the transition period.

If the euro is adopted by the private sector in anticipation of the official changeover, the country incurs a resource cost in the form of lost seignorage. Compared to the initial members of the EMU that could print Euros equal to the outstanding monetary base, a country where euroization takes place before the entry into the EMU will use real resources to obtain the Euros. The paper proposes ways to deal with this difference in treatment.
\end{abstract}

JEL Classification: E42, F33, F36

A previous version of this paper was written for the conference "Euro and Dollarization: Forms of Monetary Union in Integrating Regions", Fordham University, April 5-6, 2002. I am grateful to Tom Courchene and George von Furstenberg for insightful comments on the earlier draft, and to participants at the conference for useful suggestions. 


\section{Currency substitution in anticipation of EU accession.}

\section{Hans Genberg}

\section{Introduction.}

For countries in Eastern and Central Europe that hope to join the European Union, the process of eventually being accepted into the EMU will take some time if one is to believe official descriptions of the steps that need to be followed. It is virtually a foregone conclusion, however, that the national monies will be replaced by the Euro at the end of this transition period. Since Euros are already circulating in the economies of the twelve current members, citizens of the accession countries will already start to use them when they travel and when they engage in trade with the EMU members. In view of the impending phasing out of the domestic currency, they may also start using Euros as a store of value or in certain domestic transaction before the official changeover.

This chapter analyses the extent and consequences of spontaneous adoption of the Euro in anticipation of membership in the EMU. In the next section I discuss the likelihood that spontaneous adoption of Euros will actually come about. I argue that the drawn-out accession period will provide the opportunity to euroize before the quasi-certain end point involving official adoption of the Euro. The official changeover may even constitute a coordinating mechanism that will lead to a larger domestic use of the Euro than is frequently thought.

Section 18.3 investigates some consequences of spontaneous adoption of the Euro in the accession countries. In particular I discuss the loss of seignorage for the new members. The argument is that spontaneous euroization leads to a reduction in the local currency monetary base and therefore in the amount of Euros that the accession countries can print upon entry into the euro area. Spontaneous euroization in other words implies that new members will have to spend 
real resources to obtain Euros, whereas the original members could simply print them. I discuss whether this is something to be concerned about, and if it is, what could be done to limit its extent. A final section of the paper considers the applicability of the analysis to other countries in the world that may consider unilateral euroization or dollarization.

\section{Incentives for spontaneous dollarization.}

In the popular debate about the effects of staying outside the European Monetary Union, it has sometimes been suggested that economic agents will spontaneously adopt the Euro because of the advantages associated with using a common currency. Often the arguments start with the proposition that a firm, which is heavily dependent on exports to EMU countries and therefore invoices in Euro would avoid currency risk if it could also contract wages and other costs in this currency. Applied to the tourist industry, or other export services that have to be consumed in the selling country, the argument would go further and claim that prices of hotel and similar services will be set in Euros in those non-member countries that earn a large part of their revenues from EMU residents.

Although physical Euros have not been in existence for more than a few months, it seems that the claims that they would be adopted in domestic transactions in advanced European nonEMU countries are quite off the mark. ${ }^{1}$ There are very few signs of any noteworthy currency substitution in these countries as yet. This is also consistent with what is known about spontaneous dollarization in general; it occurs principally when the inflation rate in the domestic currency is very high and unstable, and/or when the domestic central bank has lost all credibility. Hence, there seems to be little reason to expect the Euro establishing itself in non-EMU countries

\footnotetext{
${ }^{1}$ The Euro has been adopted in Kosovo and Macedonia this is due to the virtual non-existence of a stable alternative currency arrangement.
} 
where monetary policy is stable even if they are close to Euroland both geographically and economically.

But what would happen if a country has taken a formal decision to adopt the Euro, but for administrative or practical reasons, the changeover will not take place for some substantial period of time (a year or two, say)? When it is known that the domestic money will be phased out and replaced by the euro, will that not introduce additional incentives for the private sector to anticipate the official changeover?

In this section I will investigate these questions by analyzing the incentives that may exist for increased currency substitution in the run-up to joining a monetary union as well as the obstacles that prevent it. Not surprisingly the net effect of these two forces is ambiguous. It would certainly be beneficial for some segments of the economy to be able to switch rapidly to the new currency. However, unless a critical mass of economic agents adopts the Euro simultaneously, it may not be profitable for anyone to do so. This externality gives the incumbent currency a natural advantage. A trigger that makes many agents switch their currency use in a coordinated fashion could be the announcement of the upcoming official changeover.

\subsection{Search-theoretic models of currency use.}

Theoretical models where the choice of currency for transactions is determined endogenously typically imply multiple equilibria. Applied to an international context, this means that it is possible to generate equilibria where no, one or several currencies become accepted for transactions, and are therefore held, in a country. ${ }^{2}$ Factors such as the openness of the economy and its integration with other economies will play a role in determining which outcomes are

\footnotetext{
${ }^{2}$ See Trejos and Write (1996) for an accessible illustration of how these search-theoretic models are constructed, and what kinds of conclusions they yield.
} 
possible. But these models also predict that the equilibria may not be unique. For a given set of characteristics an equilibrium with no foreign currency holdings and another equilibrium with positive foreign currency holdings are both possible. Which of the two possibilities prevails will depend on the expectations of economic agents as to the outcome. The one that is expected to prevail will actually emerge as the self-fulfilling equilibrium.

The reason for the multiplicity of equilibria is that the choice of currency is basically viewed as a coordination problem in the presence of externalities. The externality emerges because the more frequently a currency is used and accepted by others, the more useful will it be for any given individual. The coordination problem is due to the fact that any one of several currencies could potentially serve as a transactions vehicle provided that a sufficiently large number of economic agents happen to decide on it. The importance of expectations is now easily understood. If a sufficiently large number of agents expect currency A to be adopted as the transactions currency, then they will hold that currency and use it. By so doing they provide the incentives for others to use it as well, and the currency emerges as money. If expectations instead had focused on currency B, it would have been chosen as the currency in the region.

An incumbent money will have a natural advantage in this situation. It is already used and will therefore be resilient to challenges from potential alternatives. A coordinated switch by many economic agents to another currency would come about if the costs of maintaining the incumbent became very high. Alternatively, if some factor would lead to a significant change in expectations, it may be possible that a shift in currency use will take place even if the direct costs of keeping the incumbent money are not large. An official announcement that a country is on schedule to join a monetary union could generate such expectations. Contracts that extend beyond the entry into the monetary union are likely to be denominated in the new currency. Long-term savings decisions can likewise be expected to emphasize the currency of the union. To 
be sure, legal tender considerations will still give the existing money an advantage, but this advantage will surely be eroded over time as the date of the official changeover approaches.

\subsection{Informal arguments for currency substitution.}

For the current EMU members the timetable for the introduction of Euro notes and coins included a three-year period during which the old national monies continued to circulate. This was to permit institutions in the public sector and firms and households in the private sector to carry out the necessary preparations for the adoption of the new money. National changeover plans were drawn up enumerating the required preparations, and these were usually calculated to take two to three years. ${ }^{3}$

The reasons for the relative long preparation period seem to originate mainly in the public sector and are mostly related to changes in administrative routines and laws. ${ }^{4}$ In the private sector it is usually argued that a changeover can be carried out more quickly. Firms that are internationally active already have the ability to conduct business in other currencies than the local one, and smaller purely local firms usually have less complicated systems to alter. It is therefore likely that a large part of the private sector would be able to adopt a new currency relatively quickly after a decision to dollarize has been take. But will they in fact engage in spontaneous dollarization?

To answer that question, consider briefly the arguments why the demand for domestic money might fall in the transition period.

\footnotetext{
${ }^{3}$ See Genberg (1999) for a discussion of these issues in the Swedish context.

${ }^{4}$ For the first wave of EMU members, the logistics of printing euro notes and minting euro coins was a significant contributing factor for the relatively long transition period. This need not be a bottleneck for new members who can use the facilities that have already been developed for the production of additional notes and coins.
} 


\subsubsection{Money as a store of value.}

Faced with a programmed official dollarization, an investor knows that any asset denominated in the local currency will have to be changed into the new currency at the conversion date. If the investment horizon is beyond this conversion date, she might decide to complete the changeover earlier so as to match the currency composition of her assets with the currency composition of the planned future expenditures. To be sure, arguments of this type probably apply principally to the demand for broad measures of money, but indirectly this will change the demand for base money on the part of financial intermediaries.

\subsubsection{Money as a unit of account.}

Firms that trade significantly with the rest of the world are routinely managing invoices, price lists etc. in both domestic and foreign currencies. One of the cost savings associated with dollarization is presumably that there will be one less currency to deal with. To the extent possible, a firm may therefore anticipate the changeover, and phase out the domestic currency when the occasion presents itself during the transition period. While this will increase the familiarity with the new currency, it does not by itself change the demand for monetary base denominated in the domestic currency.

\subsubsection{Money as a means of transaction.}

As described by the search-theoretic models of money, the usefulness of money for transactions purposes involves an externality. The more agents that use a money, the more useful it is for an individual. Hence, to switch from the domestic money for transactions purposes requires some degree of coordination. This is why there is a presumption that the incumbent money will continue to be used heavily until the official changeover date. In some contexts, 
especially in border regions and in sectors dealing with tourism, there will be strong incentives to accept the new currency, and this may be a trigger that induces greater generalized use of this currency for transactions.

In the context it is important to note that a significant amount of currency substitution has already taken place in several in Eastern and Central European countries. This process started as a reaction to the instability and uncertain purchasing power of the existing currencies, but it persists even though a certain measure confidence has now been restored. It is therefore to be expected that the extent of currency substitution will increase once a time schedule of accession to the European Union has been established.

\section{Consequences of spontaneous adoption or the Euro in accession countries.}

\subsection{Loss of seignorage.}

New members in the Euro area will be able to print an amount of Euros that corresponds to the monetary base at the time of entry into the Euro system. If there is no spontaneous euroization in the run-up, the conversion will look exactly like that of the first wave of members that replaced their national monies with the Euro starting in January 2002. No real resources other than printing and distribution costs had to be incurred at the changeover.

If there is some spontaneous adoption of the Euro before the official introduction, the situation is different. To illustrate what might happen suppose realistically that the country has decided to maintain a fixed exchange rate vis-à-vis the Euro during the transition period. If there is no currency substitution during this period, the local coins and notes will simply be replaced by the corresponding amounts in Euros when the conversion day comes. The Euros will either be printed directly by the country in question, or the Eurosystem will provide them. 
Before the decision to euroize the domestic money supply is backed by domestic and foreign assets in the balance sheet of the central bank. As there is no currency substitution during the transition, the demand for money can be assumed not to change, so at the time of the official euroization the balance sheet is fundamentally the same as before. The stock of domestic money will simply have been replaced by the stock of Euros as the monetary assets of the private sector and the corresponding liability of the central bank. There has been no change in the net financial position of the country as a whole.

Consider now what happens if there will actually be a significant amount of spontaneous currency substitution during the transition period. Currency substitution implies a reduction in the demand for the local currency in favor of the Euros. To obtain the Euros, residents will sell the home currency in the foreign exchange market, putting pressure on the exchange rate. To prevent depreciation, the central bank intervenes resulting in a loss of foreign exchange reserves. When these reserves are exhausted, the central bank may borrow abroad in order to continue the interventions. In the balance sheet of the central bank there will be an increase in external liabilities that corresponds to the increasing domestic demand for Euros for monetary purposes. When the time comes to replace the domestic currency officially with the Euro, the remaining money supply will be replaced by Euros as before, but because of the currency substitution during the transition, the central bank's balance sheet has now been altered, in particular its net foreign asset position has deteriorated.

To prevent the deterioration of the balance sheet at the time of the changeover, the central bank would have to receive (or be able to print) Euros equal to the money in circulation at the beginning of the transition period, and not at the end. If that were done, the Euros that would not be needed to replace the domestic money in circulation could be used to restore the net foreign asset position to its level at the beginning of the transition period. 
While this solution is relatively straightforward if it is the central bank that borrows abroad during the transition, the situation will be more complicated if the central bank has induced the private sector to do so. In this case the end result will be that private sector financial intermediaries will have a negative net foreign asset position corresponding to the international borrowing it was induced to do on behalf of the central bank. At the time of the changeover to Euros, the central bank could of course exchange these liabilities for newly minted Euros, but it will not be obvious how to distinguish foreign asset positions contracted on behalf of the central bank from regular transactions that these intermediaries might have engaged in.

The solution to this problem might be that the Eurosystem provides a conversion facility in Euros to the central bank in the euroizing country for the entire amount of the monetary base at the beginning of the transition period. This conversion facility can be drawn on to stabilize the exchange rate and would be sufficient to deal with any amount of currency substitution that might occur.

\subsection{Is the loss of seignorage quantitatively important?}

The maximum size of the potential loss of seignorage is indicated in Table 1 for the ten potential accession countries. They range from $4.7 \%$ of GDP in Slovenia to $23.2 \%$ in the Czech Republic. These figures represent the upper limit of the potential loss because they would be realized only if spontaneous euroization before the official changeover was complete in the sense that the entire monetary base was transformed into Euros. ${ }^{5}$ However, even if only a fraction of this transformation were to take place, the loss to the country could be substantial.

\footnotetext{
${ }^{5}$ Note that some additional loss of seignorage has already occurred since Euros are already held in the accession countries.
} 
Table 18.1 Reserve money as a percentage of GDP in EU accession countries.

1998 Accession group

$\begin{array}{llllll}\text { Country } & \begin{array}{l}\text { Czech } \\ \text { Republic }\end{array} & \text { Estonia } & \text { Hungary } & \text { Poland } & \text { Slovenia } \\ \begin{array}{l}\text { Average } \\ 1995-1999\end{array} & 23.2 \% & 13.1 \% & 10.8 \% & 9.2 \% & 4.7 \%\end{array}$

2000 Accession group

$\begin{array}{llll}\text { Bulgaria Latvia } \quad \text { Lithuania } & \text { Romania } & \text { Slovak } \\ & \text { Republic }\end{array}$

$\begin{array}{llllll}\text { Average } & 15.7 \% & 12.7 \% & 9.5 \% & 7.9 \% & 12.9 \% \\ 1995-1999 & 19 \%\end{array}$

Source: IMF: International Financial Statistics CD-Rom and own calculations.

\subsection{Should we do anything about it?}

On equity grounds it seems unfair that new members in the EMU should have to spend real resources to obtain Euros when the original members did not. Moreover, since GDP per capita of the potential new members is generally lower, one might question the fairness of the transfer to the richer existing members resulting from uncompensated spontaneous euroization. Of course, since spontaneous euroization would be completely voluntary, the citizens are presumably better off compared to a situation where they would be prevented from using the euro during the transition. However, this does not change the fact that such euroization involves resource costs and transfers to the existing EMU members. 
It might be argued that since the new accession countries did not have to incur any of the setup costs of the Eurosystem, the transfers simply reflect contributions to these costs, a bit like an entrance fee to an exclusive club to cover the costs of building of the clubhouse. While the principle that new members of the EMU should have to contribute to the initial setup costs does have some merit, there is no reason why the size of this contribution should be related to the amount of currency substitution that takes place in the transition.

Another argument might be that the transfer represents a penalty that countries have to incur for not preventing the premature adoption of the Euro in the private sector. It is well known that the official view in the Eurosystem is quite negative regarding euroization in accession countries. It seems that they are expected to follow a path towards EMU membership that involves maintaining their own currencies and staying in an ERM2 arrangement for two years before they are considered eligible to enter the monetary union. Whatever the merit of the view that transition to EMU membership should not involve official euroization, it is not clear that a government in an accession country can do much to prevent spontaneous adoption of the Euro in the private sector. Attempts to discourage it may in fact have the opposite impact if the private sector interprets this as a sign that the domestic authorities want to preserve the demand for domestic base money in order to extract additional seignorage through inflation.

I conclude from this discussion that the transfers from accession countries to EMU members associated with spontaneous euroization is both inequitable and inefficient. It is hence important to search for ways of minimizing their size. This is the topic of the next section. 


\section{Limiting the size of the resource transfer due to euroization}

Assuming that we cannot or do not want to limit by decree the extent to which the private sector ends up using the Euro during the accession period, what can be done to limit the size of the implied resource transfer?

As already noted, one approach involves allowing the domestic authorities to print or obtain an amount of Euros equal to the size of the monetary base outstanding at the beginning of the transition period rather than at the end. This can be accomplished in several ways. One would be activated at the time of joining the monetary union and would allow the Central Bank to print an amount of Euros equal to the value of domestic-currency monetary base at the time the country joins the EU. This would ensure that all spontaneous euroization during the transition would not result in any resource loss. A similar effect could be obtained by creating a conversion facility during the transition period whereby a new EU member would be able to obtain Euros from the Eurosystem in exchange for domestic currency at a fixed conversion rate. Such a facility would make it possible to stabilize the exchange rate without losing foreign exchange reserves.

Another approach to limit the loss of seignorage would be to reduce the volume of euroization in the private sector by shortening the transition period from EU to EMU membership. When one of the accession countries enters the EU it will also commit itself to joining the EMU once it has met the convergence criteria. One of these requires membership in an ERM2 arrangement for a period of at least two years. After being admitted into the EMU but before replacing the national money with Euros it might be necessary to allow for an additional transition period in order to make the necessary technical preparations. Since newcomers have the experiences of the current members to draw on, the latter period can be made relatively short, provided some preparations are already started when the country enters the ERM2. 
We see that the real bottleneck is the two-year period spent in the ERM2 arrangement. In order to limit the potential for spontaneous euroization and the resulting transfers, it would be necessary to reduce its length substantially. As the economic arguments for maintaining such a long transition period are in any case suspect, the argument advanced here suggest that it should be modified.

\section{Final remarks.}

I have argued that the prospect of joining a currency union can constitute a triggering mechanism that induces spontaneous currency substitution in anticipation of the official changeover. The logic applies particularly to the case of those Central and Eastern European countries that aspire to become members of the European Union. Is it also relevant elsewhere?

I think the answer is yes. Consider the basic underlying logic. The extent to which the private sector uses a foreign currency (the dollar, say) in parallel with the domestic currency depends on a number of factors, among them the probability that the government will dollarize officially. In turn, the incentives for the government to do so depend in part on how dollarized the private sector already is. It is possible that these two processes interact so as to bring the country gradually closer and closer towards full dollarization both in the private sector and inescapably therefore by the government. ${ }^{6}$

The argument that dollarization involves a real transfer from the dollarizing country is also of course generally valid. In the context of the new members of the European Union I have argued on equity grounds that the relatively poor accession countries should be compensated for

\footnotetext{
${ }^{6}$ The dynamics involved is studied by the author in a separate paper provisionally entitled "Endogenous dollarization".
} 
this real transfer. Alternatively steps should be taken to reduce the transition period during which spontaneous euroization is likely to take place.

It is less clear that the compensation argument applies to countries that dollarize unilaterally. Although it would be almost costless for the United States to provide the dollars in exchange for the local currency, the equity motive for doing so does not apply with the same force exactly because the decision to dollarize is unilateral. However, on strategic grounds it may be profitable for the US to provide a country with the initial stock of dollars in order to collect the continuous flow of seignorage thereafter. This is particularly the case if the country has the alternative of giving up the domestic currency for the Euro. Analyzing the intriguing possibility that the 'dollarizing' country can extract a portion or even all the present and future seignorage gains from competing suppliers of an international money is however beyond the scope of the present paper.

\section{References.}

Genberg, Hans (2000). “Managing Sweden's Transition to EMU”. SNS Occasional Paper, No. 83 , February.

Trejos, A. and R. Wright (1996). "Search-Theoretic Models of International Currency", Federal Reserve Bank of St. Louis Review 78: May/June: 117-132. 